\title{
Global Financial Crisis and Philanthropy: \\ Malaysian Case
}

\author{
Janice L. H. Nga \\ Universiti Malaysia Sabah
}

\begin{abstract}
This paper investigates the issue of the global financial crisis and its impacts on philanthropy and civil society organisations (CSOs) in Malaysia. CSOs are popularly known as non-governmental organisations (NGOs) in Malaysia. Financial crisis has caused NGOs in many countries to receive less funding. This situation may threaten and discourage voluntary works. Undoubtedly, these beneficial contributions from the NGOs are needful services to the society. This paper examines the impact of financial crisis through the lens of NGOs and philanthropy activities in Malaysia. It utilises primary and secondary data, employs a mixed method approach, and uses quantitative and qualitative data. While there are many influencing factors in this development, this paper presents several significant aspects in the Malaysian context, including the style and nature of giving, culture, religion, and political pressure. This study attempts to seek potential solutions, pathways and possible approaches beneficial to NGOs and philanthropy activities for their sustainability in facing the financial crisis and its consequences. Experiences and lessons learnt in Malaysia may well be useful and applicable to some extent in other countries.
\end{abstract}

\section{Introduction}

In Malaysia, civil society organisations (CSOs) are popularly known as non-governmental organisations (NGOs). Conceptually, civil society is connected with the state and market to accommodate the frequently divergent interests of non-governmental organisations and citizen groups in the national development agenda (CCS, 2004). Keane (2005, p. 26), and Salamon and Anheier (1997) have claimed that civil society can foster social justice, and acts as the protector of citizens against the ravages of money-driven markets and governmental power. However, the degree of partnership between state, market and civil society varies among countries due, for example, to variations in social cohesion and levels of social participation, political economy, cultural context and historical factors. 
The strong connection between market players, politics and civil society is institutionalised and emphasised through corporate social responsibility (CSR), founded on the idea of corporate citizenship (Zadek, 2007, pp. 1, 29). The partnership between the three sectors creates new patterns of civil governance (Eberhard-Harribey, 2006, pp. 365-366; Zadek, 2007, p. 30). While the role of corporate donors is undoubtedly important to NGOs and the work of civil society, this paper also discusses philanthropy at individual level.

A range of terms emerging from different backgrounds can be used to refer to the same activity, e.g. philanthropy, charity, NGOs giving, donation. Philanthropy alone can be defined in many ways and is yet to be understood as a united theoretical concept of philanthropy (Adam, 2004, p. 4; Harrow, 2010, p. 122). However, there are two common characteristics in these definitions of philanthropy: 'private initiatives for the public good' (Gardner, 1961; Harvey, 4 August 2011; Srivastava \& Oh, 2010, p. 462) which is derived from Gardner’s classic definition and Payton’s emphasis of ‘voluntary action’ (Payton, $1988^{1}$ ). In its broadest sense, philanthropy can be seen as 'a collective form of charitable giving... [P]hilanthropists tend to impose their vision of good society ...through collective ventures' (Friedman, 2003, p. 2). This paper is not concerned with a detailed discussion of the variety in definitions, rather it focuses on philanthropic activities in time of crises especially in the Malaysian context and issues faced by civil society organisations in this context.

Civil society organisations and philanthropic activities are part of what is known as the third sector and, in any society, they are interrelated to the other sectors (see Figure 1). Thus, any international economic crisis will impact on the working of the third sector. The global financial crisis of 2008-9 has undoubtedly affected activities and organisations of civil society and philanthropy. Data from the annual survey of the Nonprofit Finance Fund in Malaysia are useful in providing insights and significant evidences to explain the situation (NFF, 2014).

Anheier (2009a, p. 4) claims that such a crisis adds new challenges to an existing complexity including the third sector and their activities. These consequences from the financial crisis are attributed to the global governance problems that refer to the growing mismatch between the

\footnotetext{
${ }^{1}$ See also http://learningtogive.org/papers/paper58.html
} 
forces of financial globalisation and the capacity to steer and regulate relevant activities in due course (Anheier 2009a, p. 1). In other words, such a crisis sets up an interplay between legitimacy, efficacy and effectiveness in the system (Anheier \& List, 2013, p. 5).

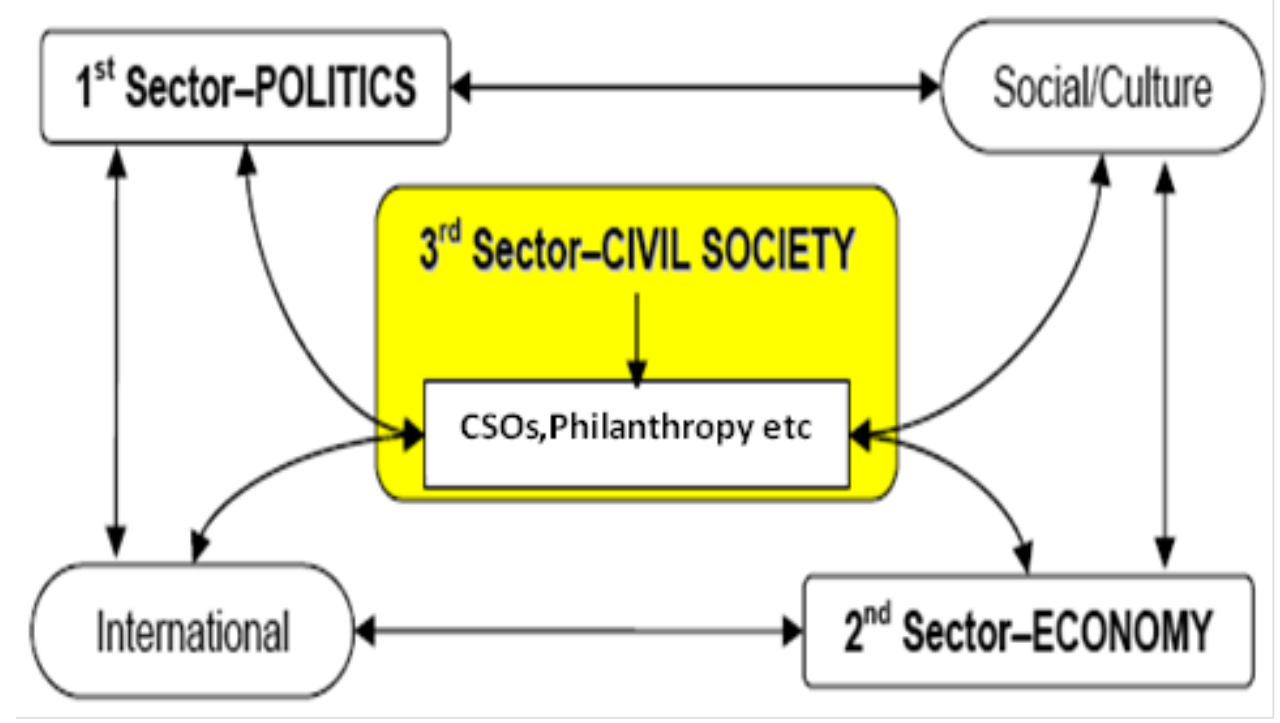

Adapted from (Nga, 2009, p. 15)

Figure 1 The Positioning of Philanthropy and Civil Society

\section{Financial Crisis and Philanthropic Activities}

The global financial crisis of 2008-2009 had a significant impact on the Malaysian economy. For instance, GDP growth in Malaysia had slowed down to $0.1 \%$ in the fourth quarter of 2008, and decreased by $-6.2 \%$ in the first quarter of 2009 and falling further by $-3.9 \%$ in the second quarter of 2009 (Mahani Zainal Abidin \& Rajah Rasiah, 2009, pp. 6, 10). While the popular views have suggested that international financial crisis negatively impacted philanthropic activities and the work of civil society organisations, there are scholars that offer different point of views. For example, Pevcin (2009, p. 30) claims that in times of financial crisis, the non-profit sector is potentially more able to mobilise resources, especially human resources, to continue its work, without necessarily having to resort to economic incentives. Breeze and Morgan (2009, p. 3), in their study of the UK fundraising appeals, found that recession need not affect giving behaviours. They argue that the popular claims about the impact of recession and financial crises are due to two important assumptions. Firstly, it is assumed that people have less money during recessions and thus donation to charity will decrease in due course. Secondly, more people are in need of help and support 
during bad times and thus there is an increase in demand for non-profit services (Breeze \& Morgan, 2009, p. 4).

Breeze and Morgan (2009, p. 3, 6) suggest that charities are subjected to many external factors, including media coverage, that influence the amount of donations received by an organisation or in an event. Among many factors related to philanthropic activities, for example donor's behaviour, donor's resources, non-profit expenditure demands and so on, they conclude that donor's care and effective communication are the more important factors in determining an act of philanthropy (Breeze \& Morgan, 2009, p. 10, 20). Waters (2009, p. 139) claims that emotional reasons for giving are important factor and have an impact on one's philanthropic action. So that, an individual who is psychologically uncomfortable with the situation he or she observes would then be motivated to reduce this discomfort through offering a contribution or becoming involved in relevant philanthropic actions and activities.

In addition, religion is another aspect to be considered in philanthropic activities, especially in times of financial crisis. Dehejia et al. (2007, p. 260) emphasise that religion is an important factor especially in influencing an individual in non-material ways such as through beliefs, attitudes and values. Religion generally offers some form of benefits and motivations for philanthropic activities, for example through 'the salvation motive', 'the consumption motive’ and 'the social-pressure motive' (Dehejia et al., 2007, p. 261).

This study investigates philanthropic activities of people practicing the major religions in Malaysia i.e. Islam and Christianity. It attempts to gather information of formal philanthropy, in cases where the beneficiary is unknown to the donor, as well as people's offering of cash, goods, and time for services to their extended family, neighbours, and community.

\section{Methodology}

This study focuses on the Malaysian context to understand the situation and adaptation in financial crises especially for the period of 2008-2011. It employs a mixed method approach, utilising primary and secondary data that consist of qualitative and quantitative data and involves the processes of searching, screening and reviewing (Srivastava \& Oh, 2010, p. 463). It investigates several major NGOs such as youth organisations and youth council, uniformed bodies, race and religion-related organisations and their work on general charitable activities. 
In this study, general charitable activities refer to objective-based and incident-based activities e.g. donations and contributions for education, tsunami, flood and other disasters.

The qualitative data in this study have been collected mainly from interviews and observations. The quantitative data includes existing published and unpublished figures from various department reports and records. Targeted data include total zakat and different components or types of zakat, fundings, donations, offering and tithe, records of tax exemption for charitable deeds financially and in-kind et cetera. Acknowledging the time and geographical constraints faced by the researcher, the data have been collected in Sabah, through access to personal networks. It is important to note that the ability to collect these data is solely based on the willingness of relevant parties to offer their data and materials.

The field study to gain qualitative data such as through interviews and observations did not face any obstacles. In terms of quantitative data, the Zakat Centre of Sabah (Pusat Zakat Sabah) offered full cooperation and revealed all figures of various categories of zakat collection in Sabah. Three officers of the financial unit were involved in the in-depth interview phase. However, gathering data on tithing and the offerings of churches was not successful. The limitations this imposed on the study are set out below as are other limitations deriving from the data collection.

\section{Limitations}

There are several limitations especially in acquiring unpublished quantitative data. Permission to access data on tithes and offerings to a main Christian denomination was first granted and then withdrawn for reasons related to the provision of the Missionary Act 147. As it is, under the said Act 147, churches do not need to submit their annual financial report to the government authority. It is one of the many privileges under this Act.

While having those figures would have been enhanced the credibility of this study, it is necessary to protect the interests of the informants and their organisations as recommended in research ethics (Saunders et al., 2009, pp. 185-193; Sekaran \& Bougie, 2010, p. 221). The limitation this lack of data imposes leads to an important observation. It had demonstrated that while churches appreciate and welcome this study, attempts to obtain figures of offerings and donations from the church council were turned down due to worries of the usage and 
misinterpretation by certain parties thereafter that may well affected the privilege enjoyed under the Act 147. This careful step of risk management shown by the particular church demonstrated that religion and race issues are still sensitive issues in the Malaysian community. In fact, the willingness to share information in interviews and through communications without hesitation (other than providing financial data) has further reflected the level of religion sensitivity in Malaysia.

\section{Giving}

\section{Faith-Based Giving}

The data in this section are limited, as noted above. The withdrawal of permission from a Christian denomination leaves the focus on zakat as the basis from which to understand the formal giving of religion-related organisation in Malaysia. Zakat is one of the five pillars of Islam. It is a form of tax and it is made compulsory for Muslims that have met the minimum requirement to be eligible to pay zakat. There are several types of zakat collected, as listed in Table 2. In translation, these can be understood as follows: 1.Zakat Fitrah is a small levy; 2.Zakat on Income; 3.Zakat on Earnings; 4.Zakat on Savings; 5.Zakat on Business; 6.Zakat on Gold \& Silver; 7.Zakat on shares; 8.Zakat on Farming; 9.Zakat on Livestock; 10.FMM (Fakir Miskin \& Mualaf) for the Poor and Needy.

Apart from zakat fitrah which is based on the price of rice (i.e. RM6.80 in 2011), all other types of zakat are calculated based on 'nisab'. In Malaysia, the nisab is a quantified amount that is equivalent to the value or worth of $85 \mathrm{gm}$ gold at market price. Table 1 shows the amount of nisab in Ringgit Malaysia over time. Table 2 shows the amount of Zakat collection over time.

\section{Table 1 Amount of Nisab in Ringgit Malaysia}

\begin{tabular}{|l|l|}
\hline Year & $\begin{array}{l}\text { NISAB=85 GM of GOLD } \\
\text { at Market Price (RM) }\end{array}$ \\
\hline 2005 & 4000 \\
\hline 2006 & 4436 \\
\hline 2007 & 4892.97 \\
\hline 2008 & 6733.70 \\
\hline 2009 & 7991.62 \\
\hline 2010 & 9000 \\
\hline 2011 & 10500 \\
\hline
\end{tabular}

Source: Zakat Kota Kinabalu (KK) Sabah. Information provided by officers of Zakat KK during visit to Zakat KK on 9 September 2011 
Table 2 Amount of Zakat Collection in Ringgit Malaysia, 2005 - 2010

\begin{tabular}{|c|c|c|c|c|c|c|}
\hline & 2005 & 2006 & 2007 & 2008 & 2009 & 2010 \\
\hline 1.Zakat Fitrah & $\begin{array}{l}3,299,221 . \\
49\end{array}$ & $\begin{array}{l}3,990,626 . \\
52\end{array}$ & $\begin{array}{l}4,392,796 . \\
95\end{array}$ & $\begin{array}{l}6,430,255 . \\
09\end{array}$ & $\begin{array}{l}6,606,501 . \\
00\end{array}$ & $\begin{array}{l}7,188,953 . \\
20\end{array}$ \\
\hline $\begin{array}{l}\text { 2.Zakat } \\
\text { Pendapatan }\end{array}$ & $205,495.76$ & $241,657.91$ & $\begin{array}{l}566,123.8 \\
4\end{array}$ & $\begin{array}{l}699,776.0 \\
2\end{array}$ & $\begin{array}{l}1,387,519 . \\
67\end{array}$ & $\begin{array}{l}1,724,872 . \\
72\end{array}$ \\
\hline $\begin{array}{l}\text { 3.Zakat } \\
\text { Penggajian }\end{array}$ & $956,904.77$ & $\begin{array}{l}1,657,486 . \\
12\end{array}$ & $\begin{array}{l}2,512,390 . \\
12\end{array}$ & $\begin{array}{l}4,152,909 . \\
41\end{array}$ & $\begin{array}{l}6,197,414 . \\
27\end{array}$ & $\begin{array}{l}7,326,246 . \\
00\end{array}$ \\
\hline $\begin{array}{l}\text { 4.Zakat } \\
\text { Simpanan }\end{array}$ & $709,970.56$ & $812,638.09$ & $\begin{array}{l}1,167,984 . \\
31\end{array}$ & $\begin{array}{l}1,191,964 . \\
45\end{array}$ & $\begin{array}{l}1,456,929 . \\
86\end{array}$ & $\begin{array}{l}1,557,341 . \\
94\end{array}$ \\
\hline $\begin{array}{l}\text { 5.Zakat } \\
\text { Perniagaan }\end{array}$ & $\begin{array}{l}5,126,351 . \\
20\end{array}$ & $\begin{array}{l}9,272,970 . \\
59\end{array}$ & $\begin{array}{l}8,136,282 . \\
09\end{array}$ & $\begin{array}{l}10,250,41 \\
0.57\end{array}$ & $\begin{array}{l}9,594,598 . \\
01\end{array}$ & $\begin{array}{l}14,962,82 \\
2.37\end{array}$ \\
\hline $\begin{array}{l}\text { 6.Zakat Emas } \\
\text { \& Perak }\end{array}$ & $14,714.88$ & $19,335.43$ & $26,698.60$ & $41,822.36$ & $63,013.29$ & $60,275.38$ \\
\hline $\begin{array}{l}\text { 7.Zakat } \\
\text { Saham } \\
\end{array}$ & $37,508.23$ & $63,914.83$ & $71,621.09$ & $74,438.51$ & $56,295.59$ & $47,597.84$ \\
\hline $\begin{array}{l}\text { 8.Zakat } \\
\text { Pertanian }\end{array}$ & $4,187.00$ & $5,934.62$ & $5,676.05$ & $6,558.74$ & $12,003.00$ & 8,310.36 \\
\hline $\begin{array}{l}\text { 9.Zakat } \\
\text { Ternakan }\end{array}$ & $10,152.00$ & $1,300.00$ & $4,525.00$ & $7,950.00$ & $26,410.00$ & $2,850.00$ \\
\hline $\begin{array}{l}\text { 10.PBP } \\
\text { (FMM) }\end{array}$ & $44,670.00$ & $93,415.00$ & $75,464.10$ & $\begin{array}{l}143,800.0 \\
0\end{array}$ & - & - \\
\hline TOTAL 1 & $\begin{array}{l}7,065,284 . \\
40\end{array}$ & $\begin{array}{l}12,075,237 \\
.59\end{array}$ & $\begin{array}{l}12,491,30 \\
1.10\end{array}$ & $\begin{array}{l}16,425,83 \\
0.06\end{array}$ & $\begin{array}{l}18,794,183 \\
.69\end{array}$ & $\begin{array}{l}25,690,31 \\
6.61\end{array}$ \\
\hline TOTAL 2 & $\begin{array}{l}10,364,505 \\
.89\end{array}$ & $\begin{array}{l}16,065,864 \\
.11\end{array}$ & $\begin{array}{l}16,884,09 \\
8.05\end{array}$ & $\begin{array}{l}22,856,08 \\
5.15\end{array}$ & $\begin{array}{l}25,400,684 \\
.69\end{array}$ & $\begin{array}{l}32,879,26 \\
9.81\end{array}$ \\
\hline TOTAL 3* & $\begin{array}{l}10,364,505 \\
.89\end{array}$ & $\begin{array}{l}16,065,864 \\
.11\end{array}$ & $\begin{array}{l}16,884,09 \\
8.05\end{array}$ & $\begin{array}{l}22,856,08 \\
5.15\end{array}$ & $\begin{array}{l}25,400,684 \\
.69\end{array}$ & $\begin{array}{l}32,879,26 \\
9.81\end{array}$ \\
\hline
\end{tabular}

Source: Zakat Kota Kinabalu (KK) Sabah. Total 1 is total of item 2 to item 9; Total 2 is total of item 1 to item 9;

Total 3 is total of all items (includes the categories for Dividen of share and Gain from Current Account, however these two categories received no contribution for the time frame).

The total collection of zakat has shown an increase over time despite the financial crises and increases of nisab due to increase in price of gold. However, it was interesting to notice that while total zakat was increasing, there were actually two types of zakat that had demonstrated some decrease in response to the financial crisis, zakat on shares and zakat on business, being two types of zakat that are collected based on situation of market or business sector. This situation was particular clear in terms of 'zakat saham' or zakat on shares. 'Zakat perniagaan' or zakat on business was the other category of zakat found to be relatively in the state of instability with some 'ups and downs' in challenging times. These data indicated that while religion was a more influential factor than other factors in formal giving, two categories mentioned above were relatively affected in financial crisis or instability in financial condition. 
It is interesting to note that zakat on gold and silver had significantly increased in bad times. This situation suggested that in times of economy uncertainty or financial crises, more Muslims were acquiring and saving more gold and silver because these materials were more stable and trustworthy to hold in possessions. This habit is not unique to Muslim or Malaysia, but it is significant globally. It is parallel with Jun's claim that one can reduce risk significantly when gold is added into a portfolio (Jun 2009, p.463).

The largest contributions of zakat were collected from areas such as Kota Kinabalu, Tawau and Sandakan. The officer from Zakat KK explained that the division of zakat contributors consists of roughly $40 \%$ from the people working in the private sectors and $60 \%$ from the government or civil servants. He claimed that in the district of Kota Kinabalu, staff of the Universiti Malaysia Sabah (UMS) were the main contributors of zakat.

Although the attempt to gain quantitative figures from the targeted church was unsuccessful, interviews with those observing the Christian faith pointed to a similar direction in philanthropy as found in people of the Muslim faith. Most Christian informants consistently used the terms 'tithe' and 'offering' (rather than donations) when they were referring to giving to church. This usage of terminology indicated that informants expressed their actions in the context of their faith and Christianity teaching. The informants stated that tithe and offerings were their privileges as Christians and that the obligation of giving back the 10 percent of tithe was not a great amount 'for all things come from God'. While it is useful information from informants, further investigation in future with figures from the administration of churches will be useful to verify the trend of giving in churches especially during financial crises.

\section{Other Organisations/Non-Faith General Giving}

Interviewees from non-faith based organisations generally claimed that fund raising and donations in time of financial crisis had been affected. They also added that with the growing numbers of NGOs in Malaysia, it was gradually becoming tougher to get support from frequent sponsors i.e. people who have normally donated in the past or philanthropists who have frequently given donations in the past (cf Williams, 2006, p. 9).

For example, informants revealed that it had been relatively tougher to get sponsorship whether it was in the forms of monetary or in-kind sponsorship. There was an incident where 
a fund raising event had to adjust the 'goodies pack' for participants due to sponsorship issues. A committee of a fundraising walk had to replace the intended sponsored t-shirt with a face towel to cut cost in order to save money and not lose money overall in the fund raising event. This situation highlighted by informants supported the findings from the zakat data that philanthropy in small and medium businesses were relatively more affected in the time of financial difficulties (for example, see Table 2 for fluctuations in item 5 and item 7).

In big corporations, philanthropic activities have been mainly determined by the policy of individual corporations. However, their support, that is donation whether in-kind or monetary, has been influenced by political pressure, community pressure and other non-systematic factors (Sasse \& Trahan, 2007, p. 30, 34). A good example would be the incident of the consortium of tycoons that intended to pay RM 2.1 billion to take control of Pan Malaysian Pools, a gaming company, and that in turn would channel the profits to fund Chinese and Tamil schools in Malaysia (Teoh, 9 August 2011). It was claimed that the takeover had received the full backing of the government. This issue had since become a controversial one because of the nature of business of the company that was the source of fund for the vernacular education.

In terms of government funding, it was stated that funding by the government and its agencies has been harder to acquire in bad times. However, the informants explained that there were sometimes exceptional cases in government funding. For example, in the case of Malaysia, informants emphasised that if an event coincides with a by-election, then accessibility to funding could be made relatively easier even during bad times, as anecdotal evidence acquitted outside the framework of this study reveals.

While there were claims that financial crisis added challenges in gaining sponsorship and affected activities of civil society organisations, informants mentioned that there were several exceptional situations where people were relatively more willing to give such as during time of disasters. Disasters include natural disasters and accidental tragedies such as fire, flood and death. For example, when Japan was hit by the earthquake and subsequent tsunami in March 2011, Malaysians donated generously to the tsunami fund despite the economy hardship in Malaysia then. To illustrate, the Girl Guide Association of Malaysia had launched the Malaysian Girl Guides-Maybank Fund for Japan’s tsunami disaster victims on 18 March 2011 (The Star, 19 March 2011). It was launched by the wife of the Malaysian Prime 
Minister. The said fund managed to collect donations amounted RM1.6 million ${ }^{2}$. Besides this particular fund, there were other organisations in Malaysia that were committed to raising funds for these twin disasters such as The Japanese Tsunami Relief Fund, UKM Disaster Fund for Earthquake and Tsunami Victims in Japan, the Tsunami Fund by the Red Crescent Society of Malaysia, the NSTP Disaster Fund-Media Prima, just to name a few ${ }^{3}$. Hence, the effort and commitment demonstrated in the case of contributing during disaster have reflected that the Malaysian community has been giving more donations when disasters occurred although the internal economy within the country was not doing too well then.

There were also examples of organisations whose level of support for their activities increased after they had established and made known their purpose to society. This situation included organisations that organise advocacy activities or advocate social accountability (Anheir, 2009b, p. 1087). For example, support from the people to 'Bersih 2.0', where Bersih is Coalition for Clean and Fair Elections increased. Donations to Bersih could be made online and there had been a handsome sum of donation collected for Bersih ${ }^{4}$. The online donation had facilitated the effectiveness of the appeal and enhanced the confidentiality of people who made donations - in other words, the identity of donors was not exposed.

In line with the development of online facilitation and motivation, another interesting example is the defence fund for Raja Petra, a blogger and activist, popularly known as RPK in 2008 (during the period of financial crisis). There was support from Malaysians around the world to recognise his effort in the democratisation process. The campaign managed to collect more than RM24,000 within 6-7 hours after it was launched. This amount far exceeded the bail amount needed i.e. RM5,000. In fact, the collection of donations was forced to cease at $5.30 \mathrm{pm}$ on the same day due to an 'overflowing' stream of donations. There were too much money and donations received in a very brief period of time. In handling the excess of funds, the remaining balance collected had been channeled to a charity of Raja Petra's choice ${ }^{5}$.

\footnotetext{
${ }^{2}$ See http://forum.lowyat.net/topic/1844669/+0

${ }^{3}$ See http://ptmbagandatoh.blogspot.com/2011/04/telugu-association-of-malaysia.html ; http://www.ukm.my/news/index.php/en/extras/635-ukm-launch-disaster-fund-for-earthquake-and-tsunamivictims-in-japan.html ; http://www.malaysia.com/blog/for-the-victims-of-japan-earthquake-tsunami-2011/

${ }^{4}$ See http://bersih.org/?p=4285

${ }^{5}$ See http://n19ba.4t.com/2008/May/Raja\%20Petra\%20charged.htm
} 
While financial constraint may be a factor in determining philanthropic activities especially during financial crises, motivation is a more significant determinant factor for giving and donating in Malaysia. This philanthropy and generous support for specific causes is interesting and clearly demonstrated in various incidents in Malaysia as the examples discussed above show.

\section{Conclusions}

While this study did not set out to demonstrate that the international financial crisis negatively affected all philanthropy activities and civil society organisations in Malaysia, it can be concluded that faith-based or religion-based philanthropic activities are relatively less affected in comparison to the non-faith based philanthropy activities, except in cases of extreme human need or of ideological commitment. Hence, further study in a wider scope is needed to investigate this situation further. In considering data from the faith-based organisations may be useful, methodological issues and accessibility to data need further attention to overcome the existing limitations (see also Westall, 2009: 5).

All in all, this paper can conclude that for the Malaysian case, the financial crisis is not the most important determinant in the decreases in philanthropic activities; rather motivation is more dominant determinant factor in philanthropy, as demonstrated through faith-based organisations and advocates of social accountability. Hence, NGOs that are involved in fund raising for social development and support to the less fortunate need to demonstrate there is a significant degree of need in order to foster support from the public to motivate them and gain funding support and donations.

\section{Acknowledgement}

This article is a revised and expanded version of a paper presented in the 'Workshop on the Impact of the International Economic Crisis on Civil Society and Philanthropy in Asia and the United States', held at the Hotel Villa Fontaine Tamachi in Tokyo, 7-9 October, 2011. The author is particularly grateful to the Osaka School of International Public Policy (OSIPP) and the International Society of Third Sector Research (ISTR, secretariat at the Johns Hopkins University) for their kind invitation to the author as a panelist. The author would like to record her appreciation to the Japan Foundation Center for Global Partnership in offering funding to the author for her transportation and accommodation costs to the workshop, as well as to OSIPP, the University of Wisconsin, and the University of Iowa for additional funding and workshop support. Special thanks to all participants for their generous comments and positive feedbacks during and after the workshop. Last but not least, appreciation is due to Universiti Malaysia Sabah (especially the Centre for Research and Innovation and Faculty of Business, Economics and Accountancy) for granting the leave and making arrangements that enabled the author to attend the event. 


\section{References}

Abidin, Mahani Zainal \& Rasiah, Rajah 2009, The global financial crisis and the Malaysian economy: impact and responses, UNDP, Kuala Lumpur.

Adam, T. 2004, Philanthropy, Charity and Civil Society: Experiences from Germany, Great Britain and North America, Indiana University Press, Bloomington.

Anheier, H. K. 2009a. The Global Economic Downturn, Philanthropy and Nonprofits: Reflections on What it Means, and What to Do, Centre for Social Investment, Heidelberg.

Anheier, H. K. 2009b. 'What kind of nonprofit sector, What kind of society? Comparative policy reflections', American Behavioral Scientist, vol. 52, pp. 1082-1094. doi: http://dx.doi.org/10.1177/0002764208327676

Anheier, H. K. \& List, R. A. 2013, The Governance Report 2013: Overview, http://www.governancereport.org/fileadmin/governancereport/2013/what_to_expect_do wnloads/GovRep2013-Factsheet_WEB.pdf

Azzi, C. \& Ehrenberg, R. G. 1975, 'Household allocation of time and church attendance', Journal of Political Economy, 83, no. 1, pp. 27-56. doi: http://dx.doi.org/10.1086/260305

Breeze, B. \& Morgan, G. G. 2009, Philanthropy in a Recession: An Analysis of UK Media Representations and Implications for Charitable Giving, Paper presented at the NCVO/VSSN Researching the Voluntary Sector Conference, 8-9 September 2009.

Centre for Civil Society (CCS), London School of Economics 2004, What is Civil Society? Accessed 1 April 2004, Available from: http://www.lse.ac.uk/collections/CCS/what_is_civil_society.htm

Dehejia, R., DeLeire, T. \$ Luttmer, E. F. P. 2007, 'Insuring consumption and happiness through religious organisations', Journal of Public Economics, vol. 91, pp. 259-279. doi: http://dx.doi.org/10.1016/j.jpubeco.2006.05.004

Eberhard-Harribey, L. 2006, 'Corporate social responsibility as a new paradigm in the European policy: How CSR comes to legitimate the European regulation process', Corporate Governance, vol. 6, no. 4, pp. 358-368. doi: http://dx.doi.org/10.1108/14720700610689487

Friedman, L. J. 2003, 'Philanthropy in America: Historicism and its discontents' in Friedman, L. J. \& McGarvie, M. (eds.), Charity, Philanthropy and Civility in American History, Cambridge University Press, Cambridge, pp. 1-22.

Gardner, J.W. 1961, Fifty Years in Review, Carnegie Corporation, New York.

Harrow, J. 2010, 'Philanthropy’ in Taylor, R. (ed.), Third Sector Research, Springer, New York, pp. 121-137. doi: http://dx.doi.org/10.1007/978-1-4419-5707-8_10

Harvey, J. 2011, Defining 'Global Philanthropy'. 4 August. Accessed 28 July 2015. Available: http://www.alliancemagazine.org/blog/defining-global-philanthropy/

Hersey, L. 2010. Government Funding of Nonprofit Organizations: Does this Reflect Democracy? Draft prepared for the 23rd Annual Meeting of the Public Administration Theory Network, Omaha, Ne. 
Jun, J. H. 2009, Global Financial Crisis and Gold Market, 2 May. Accessed 30 July 2015. Available: http://dx.doi.org/10.2139/ssrn.1397904

Keane, J. 2005, 'Eleven theses on markets and civil society', Journal of Civil Society, vol. 1, no. 1, pp. 25-34. doi: http://dx.doi.org/10.1080/17448680500166098

Nga, J. L. H. 2009. The Roles of Youth Organisations in Malaysia's Political Development, PhD Thesis, University of Leeds, UK.

Nonprofit Finance Fund 2014, 2014 State of the Nonprofit Sector (Services and Programs: Actions Taken the Previous Year). Accessed 28 July 2015. Available from: http://nonprofitfinancefund.org/files/docs/2014/2014survey brochure.pdf

Payton, R. 1988, Voluntary Action for the Public Good, Macmillan, New York.

Pevcin, P. 2009, 'Size and development of the Third Sector: An insight into cross-country differences', Uprava, vol. 7, no. 4.

Salamon, L. M. \& Anheier, H. K. 1996, 'The International Classification of Nonprofit Organisations: ICNPO-Revision 1, 1996', Working Papers of the Johns Hopkins Comparative Nonprofit Sector Project, No. 19. The John Hopkins Institute for Policy Studies, Baltimore.

Sasse, C. M. \& Trahan, R. T. 2007, 'Rethinking the new corporate philanthropy', Business Horizons, vol. 50, pp. 29-38. doi: http://dx.doi.org/10.1016/j.bushor.2006.05.002

Saunders, M., Lewis, P. \& Thornhill, A. 2009, Research Method for Business Students, (5 ${ }^{\text {th }}$ edition), Prentice Hall Financial Times, Singapore.

Sekaran, U. \&Bougie, R. 2010, Research Methods for Business: A Skill Building Approach, Wiley, London.

Srivastava, P. \& Oh, S.A. 2010, 'Private foundations, philanthropy, and partnership in education and development: Mapping the terrain', International Journal of Educational Development, vol. 30, pp. 460-471. doi: http://dx.doi.org/10.1016/j.ijedudev.2010.04.002

Teoh, S. 2011, Gaming Profits to Fund Vernacular Education. 9 August. Accessed 10 August 2011. Available from: http://terencechoong.blogspot.com/2011/08/gamingprofits-to-fund-vernacular.html

The Star 2011, Girl Guides Launch Fund to Help Victims of Twin Disasters. 19 March. Accessed 20 March 2011, Available from: http://thestar.com.my/news/story.asp?file=/2011/3/19/nation/8307014\&sec=nation

Waters, R. D. 2009, 'Examining the role of cognitive dissonance in crisis fundraising', Public Relations Review, vol. 35, pp. 139-143. doi: http://dx.doi.org/10.1016/j.pubrev.2008.11.001

Westall, A. 2009, Economic Analysis and the Third Sector: Overview of Economic Analysis in Relation to Third Sector, Third Sector Research Center Working Paper 14, September 2009, University of Birmingham.

Williams, I. 2006, What Does Competition and Collaboration Mean in the Voluntary and Community Sector? Resource Paper Compete or Collaborate Seminar, October 2006. Jointly organized by the NCVO Third Sector Foresight Project and Performance Hub.

Zadek, S. 2007, The Civil Corporation: The New Economy of Corporate Citizenship, Earthscan, London 